Elena Savinets \& Vladislav Karelin (2019) Formy, metody ta pryntsypy administratyvno-pravovoho zabezpechennya mobilizatsiyi Zbroynykh Syl Ukrayiny [Forms, methods and principles of the administrative and legal framework of mobilization of the Armed Forces of Ukraine]. Social development \& Security. 9(4), 87 - 101. DOI: http://doi.org/10.33445/sds.2019.9.4.6

\title{
Форми, методи та принципи адміністративно-правового забезпечення мобілізації Збройних Сил України
}

\author{
Олена Савинець *, Владислав Карелін ** \\ * Військовий інститут Київського національного університету імені Тараса Шевченка, \\ вул. Ломоносова, 81, м. Київ, 03022, Україна, \\ e-mail:vshulgin@ukr.net, \\ к.ю.н., \\ викладач кафедри правового забезпечення факультету фінансів і права.
}

** Академія Державної пенітенціарної служби,

вул. Гонча, 34, м. Чернігів, 14000, Україна,

e-mail:vshulgin@ukr.net,

к.ю.н.

доиент кафедри кримінального, кримінально-виконавчого права та кримінології.

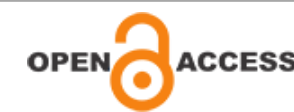

Article history:

Received: June, 2019

1st Revision: July, 2019

Accepted: August, 2019

УДК 342.9: 355.2

Анотація: У статті досліджуються існуючі форми, методи та принципи адміністративно-правового забезпечення мобілізації Збройних Сил України. Встановлено, що адміністративно-правове забезпечення мобілізації Збройних Сил України здійснюється у правотворчій, правозастосовній та контрольно-наглядовій формах. Висвітлено питання застосування методів переконання та адміністративний примус, за допомогою яких здійснюється адміністративно-правове забезпечення мобілізації Збройних Сил України. Запропоновано удосконалити систему принципів державного управління, яка застосовується для адміністративно-правового забезпечення мобілізації Збройних Сил України.

Ключові слова: адміністративно-правове забезпечення, мобілізація ЗСУ, методи, форми та принципи, військово-патріотичне виховання, контроль та нагляд, адміністративний примус, адміністративно-правовий договір.
\end{abstract}

\section{1. Формулювання проблеми}

Внаслідок ситуації, що склалася на сході України, та анексії Автономної Республіки Крим, наша країна з 2014 року перебуває у стані війни, в наслідок чого в Україні протягом 2014-2015 років було проведено шість хвиль часткової мобілізації.

Мобілізація $є$ одним 3 елементів системи оборонних заходів держави, необхідність якої полягає в тому, що утримання в мирний час військовослужбовців в тій кількості, яка була б достатньою для відсічі збройній агресії або веденню повномасштабної війни, є надзвичайно обтяжливим та руйнівним для економіки навіть потужних в економічному плані країн. 
За час проведення часткової мобілізації в Україні виникла значна кількість проблем та недоліків у адміністративно-правовому забезпеченні цієї сфери, які негативно вплинули на проведення мобілізаційних заходів тоді, коли цілісність та недоторканність нашої держави опинилися під загрозою.

Вбачається важливість у питанні форм, методів та принципів у сфері адміністративно-правового забезпечення мобілізації Збройних Сил України, оскільки аналіз цих категорій дозволить впроваджувати у практику нові форми управління, удосконалювати методи правового впливу на відносини, які виникають у сфері мобілізаційної підготовки та мобілізації. Також, досвід проведення Антитерористичної операції (далі - АТО) та Операції об’єднаних сил, а також закріплення у Конституції України стратегічного курсу держави на набуття повноправного членства України в Організації Північноатлантичного договору викликали необхідність і у вдосконаленні принципів мобілізаційної підготовки та мобілізації.

\section{2 Аналіз останніх досліджень та публікацій}

Проблемам та недолікам адміністративно-правового забезпечення мобілізації ЗСУ не приділялося значної уваги вітчизняними вченими. Водночас, дослідження адміністративно-правового забезпечення національної безпеки держави здійснювалося такими науковцями: В. І. Гейко, І. М. Коропатнік, В. Й. Пашинський, С. В. Пєтков, А. П. Поляков І. М. Шопіна, В. В. Шульгін, В. В. Сокуренко.

\section{3. Постановка завдання}

Враховуючи вищезазначене, метою статті $є$ розгляд та аналіз існуючих форм, методів та принципів адміністративно-правового забезпечення мобілізації 3СУ, виявити проблемні аспекти даної сфери, а також запропонувати можливі шляхи їх вирішення.

\section{2. Виклад основного матеріалу}

Однією зі складових механізму адміністративно-правового регулювання $є$ форми й методи, які застосовуються для забезпечення його організації та діяльності [1].

Оскільки поняття адміністративно-правового забезпечення є похідним від поняття адміністративно-правового регулювання, то реалізація завдань і функцій системи органів адміністративно-правового забезпечення мобілізації Збройних Сил України (далі - ЗСУ) здійснюється за допомогою певних форм адміністративно-правового забезпечення.

Погоджуємося $з$ думкою науковців, які під поняттям форм адміністративноправового забезпечення розуміють правові форми державного управління, вважаючи таке ототожнення логічним і доцільним [2, с. 142]. 
Як визначає В. Б. Авер'янов, під формами державного управління слід розуміти відмінні за своїм характером i наслідками способи зовнішнього вираження діяльності органів виконавчої влади. Говорити про форми управління, на його думку, доцільно лише щодо такої діяльності, яка має владноорганізуючу спрямованість і відображає зміст основних, профільних функцій органів виконавчої влади. Щодо цих форм вирішальним $є$ поділ їх на види залежно від настання тих чи інших правових наслідків [3, с. 87].

Незважаючи на те, що серед науковців не досягнуто одностайності в питанні класифікації форм державного управління, спільними є їх погляди на поділ форм державного управління на правові й неправові.

Неправові форми державного управління поділяються на організаційнотехнічні дії (розробка програм, проведення нарад, контроль, роз'яснення тих чи інших заходів) і матеріально-технічні дії (робота 3 інформацією, проведення досліджень, розробок, підготовка i видання актів, ведення діловодства, складання довідок) [4, с. 17].

На думку В.Б. Авер'янова, до неправових належать форми, які безпосередньо юридичного значення не мають і не спричиняють виникнення конкретного юридичного результату, якими найчастіше $є$ різноманітні організаційні дії службовців органів виконавчої влади на різних етапах підготовки й виконання управлінських рішень [3, с. 87].

До основних правових форм управління науковець відносить такі:

1) видання правових актів управління (нормативного й індивідуального характеру);

2) укладання адміністративних договорів (угод);

3) вчинення (здійснення) інших юридично значущих дій [3, с. 88].

Варто звернути увагу також на те, що деякі науковці розрізняють за критерієм змісту правоустановчі та правозастосовчі форми [5, с. 37].

На нашу думку, саме таку класифікацію форм державного управління можна застосувати i до сфери адміністративно-правового забезпечення мобілізації ЗСУ.

Що стосується правоустановчих форм, то для належного забезпечення функціонування сфери мобілізаційної підготовки (далі - МП) й мобілізації суб'єктами забезпечення цієї сфери створюються правові норми та правила поведінки, які регулюють ці суспільні відносини з позиції законодавця.

Деякі науковці доходять висновку, що результатом правотворчої діяльності $\epsilon$ право як таке, виражене не лише в законодавчих актах, а й у формі будь-якого джерела права. Саме тому підтримуємо позицію, що розуміння правотворчості як діяльності зі створення лише законів не можна вважати прийнятним [6, с. 191].

Скакун О.Ф. визначає правотворчість як один із етапів правоутворення організаційно оформлену діяльність уповноважених суб'єктів з ухвалювання, зміни та скасування правових норм, яка здійснюється відповідно до суспільних потреб у нормативно-правовому регулюванні [7, с. 293].

Як зауважує С. Михалюк, важливою ознакою правотворчості як складової державного управління є соціальна обумовленість, яка полягає в тому, що межі впливу правотворчої діяльності на різні сфери суспільного життя й межі 
здійснення державного управління збігаються, оскільки нормативно-правові акти, що є результатом правотворчості, безпосередньо впливають на можливості здійснення державного управління [6, с. 191].

Принципи організації та функціонування системи МП та мобілізації визначаються органом законодавчої влади України у формі ухвалення основних спеціалізованих законів України, таких як «Про оборону України», «Про мобілізаційну підготовку та мобілізацію» (далі - Закон), «Про Збройні Сили України» та інших.

Також ця сфера регулюється підзаконними нормативно-правовими актами, до яких належать постанови Кабінету Міністрів України (далі - КМУ) й укази Президента України, та великою кількістю відомчих нормативно-правових актів. Особливістю законодавства, яке регулює сферу МП та мобілізації, є те, що питання організації МП та мобілізації належать не лише до компетенції профільного міністерства, а саме Міністерства оборони України (далі Міноборони), а також і до компетенції інших центральних органів виконавчої влади, які, у свою чергу, також видають відомчі нормативні акти 3 питань урегулювання цієї сфери в межах певного міністерства.

Правозастосовна форма адміністративно-правового забезпечення мобілізації Збройних Сил України полягає у конкретній діяльності суб'єктів адміністративноправового забезпечення цієї сфери з реалізації правових норм. Вона здійснюється через видання індивідуальних (виконавчо-розпорядчих) актів управління, укладання адміністративно-правових договорів i вчинення у визначеному законодавством порядку інших дій, що мають юридичне значення [5, с. 37].

Заслуговує на увагу питання укладення договорів у сфері МП та мобілізації.

Так, відповідно до Закону установлено, що мобілізаційні завдання (замовлення) - це окремі вимоги мобілізаційного плану щодо номенклатури, обсягів виробництва необхідної продукції, утворення й підготовки до розгортання спеціальних формувань, а також затверджені в установленому порядку першочергові заходи МП, які доводяться для виконання до відома центральних і місцевих органів виконавчої влади, інших державних органів, Ради міністрів Автономної Республіки Крим та органів місцевого самоврядування. До відома підприємств, установ та організацій, що залучаються до виконання мобілізаційних завдань (замовлень), мобілізаційні завдання (замовлення) доводяться на підставі затверджених основних показників мобілізаційного плану й договорів (контрактів), що укладаються в порядку, передбаченому законодавством [8].

Водночас статтею 21 згаданого закону до обов'язків підприємств, установ та організацій щодо МП й мобілізації віднесено обов'язок планувати та здійснювати заходи щодо розробки мобілізаційних планів і підготовки до виконання покладених на них мобілізаційних завдань (замовлень) і забезпечення поставки продукції згідно з укладеними договорами (контрактами); також вони мають надавати звіти з цих питань відповідним органам виконавчої влади, іншим державним органам та органам місцевого самоврядування, які $є$ замовниками мобілізаційних завдань (замовлень) [8]. 
На нашу думку, можна стверджувати, що цей вид контрактів має адміністративно-правову природу та $\epsilon$ прикладом правозастосовної форми адміністративно-правового забезпечення мобілізації Збройних Сил України, оскільки містить у собі ознаки адміністративного договору.

Адміністративний договір $є$ різновидом публічно-правового договору. У системі правових зв'язків він посідає проміжне місце між адміністративним актом (одностороннє волевиявлення державного органу влади) та договором приватноправового характеру [9, с.1; 10, с. 243].

Вирішальною ознакою суб'єктивного складу адміністративного договору науковці вважають наділення однієї зі сторін владною управлінською функцією, а тому такий вид договору виникає тільки у сфері адміністративно-правових відносин. Крім зазначеного, до ознак адміністративного договору відносять також юридичну нерівність сторін, що виражається у виняткових повноваженнях управненої сторони договору; публічно-правовий характер договірних зобов’язань; імперативно визначені умови договору за способом конструювання, а також мету договору - задоволення публічних інтересів (домінування суспільних цілей) $[11$, с. $80 ; 12$, с. 489].

Деякі дослідники до ознак адміністративного договору відносять ще неможливість односторонньої відмови від виконання зобов' язань і неможливість односторонньої зміни умов договору.

Підтвердженням адміністративно-правової природи контракту на виконання мобілізаційного завдання є те, що підприємства, установи й організації не можуть відмовлятися від укладання договорів (контрактів) на виконання мобілізаційних завдань (замовлень), якщо їх можливості 3 урахуванням мобілізаційного розгортання та переданих їм матеріально-фінансових ресурсів дають змогу виконати ці мобілізаційні завдання (замовлення) [8]. Згадана позиція підтверджується, на нашу думку, також метою укладення контрактів на виконання мобілізаційних завдань, які спрямовано на впорядкування надзвичайно важливих правовідносин і задоволення суспільних потреб.

Аналізуючи форми адміністративно-правового забезпечення мобілізації 3СУ, погоджуємося 3 думкою вчених, які окремою формою державного управління в сфері адміністративно-правового забезпечення вважають державний контроль, який розглядають водночас і як одну 3 найважливіших функцій державного управління[2, с. 144]. Ця форма, на думку Р. А. Калюжного, знаходить свій вияв у контрольно-наглядовій діяльності. Важко не погодитися 3 науковцем у тому, що така діяльність надає можливість своєчасно виявляти причини порушень і виправляти стан справ у процесі.

Безумовно, однією з головних цілей контрольно-наглядової діяльності $\epsilon$ своєчасне виявлення різних порушень i ïх винуватців, але кінцевою метою як контролю, так і нагляду все ж таки є виправлення й усунення порушень [5, с. 37].

Варто зазначити, що позиції вчених щодо визначення поняття контролю різняться. Водночас, на нашу думку, вдалим $є$ визначення контролю як самостійної чи зовнішньо ініційованої діяльності уповноважених на те суб'єктів, спрямованої на встановлення фактичних даних щодо об'єктів цього контролю для визначення ii відповідності/невідповідності тим правомірним оцінним 
критеріям, які передбачають застосування адекватних отриманому результатові заходів реагування в унормованому порядку [13 с. 13].

Контрольна діяльність держави виражається у формі інспектування, перевірки відповідності діяльності органів держави й посадових осіб законам та актам вищих органів шляхом перевірки виконання посадових обов'язків, дотримання встановлених стандартів, правил тощо [4, с. 18].

Не викликає сумніву важливість контрольної діяльності у сфері МП та мобілізації, яку спрямовано на виявлення недоліків i правопорушень в організації МП та реалізації заходів з мобілізації Збройних Сил України.

Обов’язок здійснення контрольної діяльності у сфері МП та мобілізації покладено законодавством на керівників органів державної влади, інших державних органів, органів місцевого самоврядування, а також підприємств, установ та організацій [8]. Також у разі оголошення мобілізації контроль за здійсненням заходів щодо переведення ЗСУ, інших військових формувань та Оперативно-рятувальної служби цивільного захисту на організацію та штати воєнного часу у межах своїх повноважень здійснює КМУ [8].

Безпосередньо організація здійснення заходів з МП та мобілізації й контроль за здійсненням цих заходів в органах державної влади, інших державних органах, органах місцевого самоврядування, на підприємствах, в установах та організаціях, які мають мобілізаційні завдання (замовлення), покладаються на їх мобілізаційні підрозділи або призначених працівників із питань мобілізаційної роботи [8].

Також важливим суб'єктом здійснення контрольної діяльності у сфері МП та мобілізації $є$ військові комісаріати, на які відповідно до законодавства покладено такі контрольні функції:

1) здійснення контролю за проведенням на підприємствах роботи з ведення військового обліку військовозобов'язаних, у тому числі резервістів, а також призовників і бронювання військовозобов'язаних на період мобілізації та на воєнний час;

2) взаємодія 3 місцевими держадміністраціями, органами місцевого самоврядування й участь у здійсненні контролю за підготовкою підприємств до виконання мобілізаційних завдань (замовлень) щодо забезпечення в особливий період потреб ЗСУ;

3) участь у межах своїх повноважень у здійсненні контролю за виконанням мобілізаційних заходів у місцевих держадміністраціях, інших державних органах, органах місцевого самоврядування, а також на підприємствах; виконання заходів, спрямованих на забезпечення потреб 3СУ, інших військових формувань, правоохоронних органів спеціального призначення, Держспецтрансслужби та Держспецзв'язку у людських і транспортних ресурсах;

4) контроль організації приписки допризовників до призовних дільниць [8].

Розглядати форми адміністративно-правового забезпечення неможливо без характеристики методів, за допомогою яких здійснюється ця діяльність.

Як зауважує В. Б. Авер'янов, науковці дають методу управління схоже визначення - він розглядається ними як спосіб чи засіб впливу. На підставі різних визначень цього поняття вчений зазначає, що категорія методу управління в 
концентрованій формі відображає взаємозв'язок керуючих i керованих підсистем, за яким перша, що є суб'єктом управління, здійснює управлінський вплив на другу - керований об'єкт [3].

На думку Т. О. Коломоєць, методами державного управління є сукупність засобів здійснення управлінських функцій держави та впливу суб’єктів державного управління на об'єкти [14].

Як вважає Р. А. Калюжний, метод дозволяє мати необхідне уявлення про функціонування системи забезпечення, оскільки визначає характер впливу конкретного суб'єкта на відповідний об'єкт [5, с. 39].

Варто зазначити, що чимало вчених розглядає метод правового регулювання в двох аспектах: як основний, або загальний метод, властивий системі права загалом, і як галузевий метод правового регулювання, який відображає своєрідність впливу галузі права на суспільні відносини, спрямований безпосередньо на формування й вираження зовні можливої та належної поведінки суб'єктів, регульованих цією галуззю права відносин [15, с. 57].

Як зазначає С. О. Кузніченко, незважаючи на різні підходи до класифікації методів державного управління, універсальними методами й такими, що використовуються в усіх сферах та на всіх рівнях, є переконання та примус.

Також вважаємо за необхідне погодитися 3 науковцем стосовно того, що деякі вчені, попри те, підтримують погляди щодо виокремлення поряд із переконанням ще й такого методу, як заохочення. На нашу думку, заохочення $є$ окремим видом переконання разом із роз'ясненням, вихованням тощо [16, с. 338].

На думку Ю. П. Битяка та Б. В. Зуй, переконання - це система методів правового й неправового характеру, здійснювана державними та громадськими органами, яка проявляється у застосуванні виховних, роз'яснювальних i заохочувальних заходів із метою формування у громадян розуміння необхідності чіткого виконання вимог законів та інших правових актів [17, с.107].

Слід також закцентувати увагу на тому, що на думку згаданих учених у сфері державного управління такий метод проявляється через організацію державних i громадських заходів, спрямованих на вирішення конкретних завдань; виховання (економічне, правове, моральне та ін.), роз'яснення завдань державного управління, інструктаж осіб підпорядкованого апарату і загальної діяльності 3 питань найбільш дієвого виконання поставлених завдань, заохочення (моральне - подяка, нагородження почесним знаком, присвоєння почесного звання, матеріальне - грошові премії, путівки окремим особам або групам осіб та ін.) або критику роботи й поведінки окремих осіб [17, с.107].

На нашу думку, ефективним для забезпечення належного функціонування сфери МП та мобілізації може бути саме метод переконання, а саме такий його прояв, як військово-патріотичне виховання молоді.

Погоджуємося із М. А. Крушельницьким у тому, що мета військового виховання являє собою формування в особового складу морально-психологічної готовності до опанування військовою професією, патріотичного ставлення до виконання свого військового обов'язку у мирний час і готовності до його виконання в умовах бойових дій [18, с.153]. На його думку, військове виховання $\epsilon$ тісно пов'язаним з усіма іншими видами виховання, що викликає нагальну 
потребу у створенні цілісної державної програми підготовки майбутніх захисників, об'єднавши умовний трикутник «загальноосвітні школи - вищі навчальні заклади - армія» в єдине ціле з метою сформувати свідомого, сильного українського воїна-патріота [18, с.153].

Міноборони організовано низку заходів із метою проведення роботи 3 питань військово-патріотичного виховання, а саме: вшанування пам'яті військовослужбовців - героїв АТО через присвоєння звання «Почесний громадянин», установлення почесних дошок, найменування навчальних закладів, вулиць на їх честь тощо [19].

Також зусиллями оборонного відомства забезпечено:

проведення «уроків мужності» 3 учнями навчальних закладів загальної середньої освіти та допризовною молоддю;

проведення Днів відкритих дверей із запрошенням представників органів державної влади, місцевого самоврядування, громадських організацій, Героїв України, учасників АТО та допризовної молоді;

проведення всеукраїнських і регіональних акцій пам’яті, національнопатріотичних проектів, спрямованих на зміцнення державності, консолідацію українського народу, патріотичне виховання молоді тощо;

підготовку матеріалів для системних рубрик про героїчні вчинки військовослужбовців учасників АТО в засобах масової інформації;

публікацію у центральних i військових друкованих засобах масової інформації аналітичних матеріалів, статей та інтерв'ю про проявлення військовослужбовцями ЗСУ героїзму й мужності;

створення відеофільмів і телесюжетів про військовослужбовців-героїв [19].

Водночас вважаємо, що про неналежну організацію в державі такого виду виховання молоді, який повинен сформувати у неї розуміння необхідності виконання свого конституційного обов'язку із захисту Вітчизни, можна стверджувати за результатами проведення осіннього призову 2018 року, коли в місті Києві рекордно впала явка у військові комісаріати. За інформацією, наданою представниками цих комісаріатів, ситуація із призовом була критичною навіть порівняно з 90-ми і двохтисячними роками і гіршою, ніж під час весняного призову цього ж року, що свідчить про те, що хвиля патріотизму, яка була присутня в державі у 2014-2016 роках, поступово згасає [20].

На підставі аналізу національного законодавства можна зробити висновок, що реалізація заходів адміністративно-правового забезпечення мобілізації ЗСУ здійснюється головним чином за допомогою державного примусу.

Слід зауважити, що в законодавстві України не лише відсутнє визначення адміністративного примусу, а i сам термін «адміністративний примус» $у$ нормативних актах взагалі не зустрічається [21].

Водночас В. Б. Авер'янов розглядає державний примус і його складову примус адміністративний як одну з невід'ємних складових здійснення державної влади, як іï метод. У свою чергу, під адміністративним примусом він розуміє застосування відповідними суб'єктами до осіб, які не перебувають у їх підпорядкуванні, незалежно від волі й бажання останніх, передбачених адміністративно-правовими нормами заходів впливу морального, майнового, 
особистого (фізичного) й іншого характеру 3 метою охорони відповідних суспільних відносин шляхом попередження та припинення правопорушень, а також покарання за їх учинення [3].

Також під державним примусом науковці розуміють закріплений у нормах права вплив держави на волю суб'єктів із метою узгодження їх поведінки 3 інтересами суспільства та держави, що і здійснюється в правозастосовній діяльності [22, с.109].

Водночас не можемо не погодитися 3 О. Ткалею щодо питання взаємовідношення адміністративно-правового примусу та адміністративноправових заходів, а саме стосовно того, що вони співвідносяться між собою як частина та ціле, оскільки адміністративно-правові заходи - це не лише примусові заходи адміністративного впливу, вони містять ще й цілий комплекс заходів організаційно-правового характеру, спрямованих на невизначене коло осіб, заходи з організації комплексної діяльності щодо виявлення правопорушень та усунення їх причин та умов, вироблення стратегічних, тактичних i методологічних завдань зазначеної діяльності та створення умов для правомірного функціонування державного апарату [23, с. 434].

Крім того, науковцями наводяться такі ознаки адміністративного примусу, які відрізняють його від інших видів державного примусу:

1) він є об'єктивно необхідним методом, цілеспрямованим способом поведінки, набором певних дій і засобів, які повторюються та сприяють вирішенню завдань соціального й державного управління, застосовуються на підгрунті переконання у сфері реалізації виконавчо-розпорядчої діяльності держави;

2) він має офіційний, державно-владний характер, його застосування здійснюється лише від імені держави уповноваженими державними органами та їх посадовими особами в процесі реалізації ними державно-владних повноважень, звідси й впливає характер примусової діяльності [24, с. 83, с.123].

Так, за допомогою методу адміністративного примусу реалізуються такі заходи адміністративно-правового забезпечення мобілізації ЗСУ, як проведення призову та виконання військово-транспортного обов'язку. Це, на нашу думку, підтверджується статтею 65 Конституції України, яка встановлює обов’язок усіх громадян нашої держави щодо захисту Вітчизни, незалежності та територіальної цілісності України й шанування їі державних символів. Також відповідно до статті 35 Конституції ніхто не може бути увільнений від своїх обов'язків перед державою або відмовитися від виконання законів за мотивами релігійних переконань. У разі, якщо виконання військового обов'язку суперечить релігійним переконанням громадянина, воно має бути замінене альтернативною (невійськовою) службою [25].

На нашу думку, позитивні результати адміністративно-правового забезпечення мобілізації ЗСУ можуть бути досягнуті за умови дотримання відповідних принципів цієї діяльності.

Принципи як поняття теорії відображають сутність і реальність процесів державного управління, підпорядковуючись певним законам. На практиці принципами управління керуються згідно 3 політичними, соціальноекономічними та культурними умовами, що склалися в суспільстві [26, с.108]. 
Під принципами державного управління вчені розуміють закономірності, відносини, взаємозв'язки й керівні засади, на яких грунтуються його організація та здійснення і які можуть бути сформульовані в певні правила [27, с.38].

Також такі науковці, як Ю.В.Ковбасюк, К. О. Ващенко, Ю. П. Сурмін визначають принципи державного управління як фундаментальні істини, позитивні закономірності, керівні ідеї, основні положення й норми поведінки, що відображають закони розвитку відносин управління, сформульовані у вигляді певного наукового положення, закріпленого переважно у правовій формі, на основі якого будується та функціонує апарат державного управління. Погоджуємося 3 ними в тому, що принципи визначають вимоги до системи, структури, організації та процесу управління, напрями й межі ухвалення управлінських рішень [26, с.108-109].

Варто зауважити, що в науці не склалося єдиного підходу і до питання класифікації згаданих принципів.

Так, наприклад, на думку Т. О. Коломоєць, державне управління здійснюють на підставі таких принципів:

1) соціально-політичні: демократизм, участь населення в управлінській діяльності, рівноправність осіб, рівність усіх перед законом, законність, гласність, Урахування громадської думки, об’єктивність;

2) організаційні принципи побудови апарату державного управління: галузевий, функціональний, територіальний;

3) організаційні принципи функціонування апарату державного управління: нормативність діяльності, єдиноначальність, колегіальність, поділ управлінської праці, відповідальність за свої рішення, оперативна самостійність [14].

Водночас притримуємося точки зору вчених, які поділяють принципи державного управління на загальні (законність, гласність, участь громадян у державному управлінні, відповідальність держави перед людиною за свою діяльність) i спеціальні (галузевий, міжгалузевий, або функціональний, територіальний, поєднання централізації та децентралізації, поєднання єдиноначальності й колегіальності) [28].

Слід зауважити, що Законом визначено такі принципи МП та мобілізації:

централізоване керівництво;

завчасність;

плановість;

комплексність і погодженість;

персональна відповідальність за виконання заходів щодо МП та мобілізації; додержання прав підприємств, установ та організацій і громадян;

гарантована достатність;

наукова обгрунтованість;

фінансова забезпеченість [8].

\section{3. Висновки і перспективи подальших досліджень}

Враховуючи вищезазначене, вважаємо, що принципами адміністративноправового забезпечення мобілізації ЗСУ $є$ основоположні керівні ідеї й наукові 
засади, відповідно до яких створюються умови для належної реалізації мобілізаційних заходів.

Спираючись на вищезгаданий науковий підхід до класифікації принципів державного управління, вважаємо за доцільне здійснити поділ принципів адміністративно-правового забезпечення мобілізації ЗСУ таким чином:

загальні принципи (законності, невідворотності відповідальності за противоправну поведінку);

спеціальні (що стосуються лише адміністративно-правового забезпечення мобілізації 3СУ).

На нашу думку, доцільним є доповнення системи принципів МП та мобілізації такими:

налагодження взаємодії між органами державної влади у сфері МП та мобілізації;

відкритість для дієвого контролю у сфері мобілізаційної підготовки та мобілізації;

розвиток міжнародного співробітництва $з$ державами-членами НАТО.

Вважаємо, що адміністративно-правове забезпечення сфери мобілізації Збройних Сил України здійснюється у правоустановчій та правозастосовній формах.

Погоджуємося 3 думкою тих вчених, які окремою формою державного управління в сфері адміністративно-правового забезпечення вважають державний контроль.

Аналіз чинного законодавства надає можливість стверджувати, що методами, які застосовуються для адміністративно-правового забезпечення мобілізації ЗСУ, є переконання та примус. Ефективним для забезпечення належного функціонування сфери мобілізаційної підготовки та мобілізації може бути саме метод переконання, а саме такий його прояв як військово-патріотичне виховання молоді.

Author details (in Russian)

Формы, методы и принципы административно-правового обеспечения мобилизации Вооруженных Сил Украины

\section{Елена Савинец *, Владислав Карелин **}

* Военный институт Киевского национального университета имени Тараса Шевченко,

ул. Ломоносова, 81, г. Киев, 03022, Украина,

e-mail:vshulgin@ukr.net,

к.ю.н.,

преподаватель кафедры правового обеспечения факультета финансов и права.

** Академия Государственной пенитенщиарной службы,

ул. Гончая, 34, г. Чернигов, 14000, Украина,

e-mail:vshulgin@ukr.net,

к.ю.н.,

дочент кафедры уголовного, уголовно-исполнительного права и криминологии. 
Аннотация: В статье исследуются существующие формы, методы и принципы административно-правового обеспечения мобилизации Вооруженных Сил Украины. Установлено, что административно-правовое обеспечение мобилизации Вооруженных Сил Украины осуществляется в правотворческой, правоприменительной и контрольно-надзорной формах. Освещены вопросы применения методов убеждения и административного принуждения, с помощью которых осуществляется административно-правовое обеспечение мобилизации Вооруженных Сил Украины. Предложено усовершенствование системы принципов государственного управления, которая применяется для административноправового обеспечения мобилизации Вооруженных Сил Украины.

Ключевые слова: административно-правовое обеспечение, мобилизация Вооруженных Сил Украины, методы, формы и принципы, военно-патриотическое воспитание, контроль и надзор, административное принуждение, административно-правовой договор.

\title{
Author details (in English)
}

\section{Forms, methods and principles of the administrative and legal framework of mobilization of the Armed Forces of Ukraine}

\author{
Elena Savinets *, Vladislav Karelin ** \\ * Military Institute of Taras Shevchenko National University of Kyiv, \\ 81, Lomonosov str., Kyiv, 03022, Ukraine, \\ e-mail:vshulgin@ukr.net, \\ Ph.D., \\ lecturer, Department of Legal Support, Faculty of Finance and Law. \\ ** Academy of the State Penitentiary Service, \\ 34, Goncha, st. Chernihiv, 14000, Ukraine, \\ e-mail:vshulgin@ukr.net, \\ Ph.D., \\ associate Professor of the Department of Criminal, Criminal Enforcement and Criminology.
}

Abstract: The article examines the existing forms, methods and principles of administrative and legal support for the mobilization of the Armed Forces of Ukraine. It was established that administrative and legal support for the mobilization of the Armed Forces of Ukraine in law-making, law-enforcement, and supervisory forms. The issues of the application of methods of persuasion and administrative coercion, with the help of which the administrative and legal support of the mobilization of the Armed Forces of Ukraine is carried out, are highlighted. The proposed improvement of the system of principles of public administration, which is used for administrative and legal support for the mobilization of the Armed Forces of Ukraine.

Keywords: administrative and legal support, mobilization of the Armed Forces of Ukraine, methods, forms and principles, military-patriotic education, control and supervision, administrative coercion, administrative-legal contract.

\section{Використана література}

1. Білько К. Ф. Форми і методи адміністративно-правового регулювання організації та діяльності нотаріату. Правова держава. 2015. Вип. 26. С. 542-549.

2. Філіппов А. В. Адміністративно-правове забезпечення безпеки цивільної авіації в Україні : дис. .... канд. юрид. наук : 12.00.07. Київ, 2010. 246 с.

3. Адміністративне право України. Академічний курс : підруч. : у 2 т. : Т. 1. Загальна частина / ред. колегія: В. Б. Авер'янов (голова). Київ : Юридична думка, 2004. 584 с. 
4. Бліхар М. М. Методи адміністративно-правового регулювання інвестиційної діяльності в Україні // Lviv Polytechnic National University Institutional Repository. C. 16-21. URL: http://http://ena.lp.edu.ua/bitstream/ntb/26599/1/004-016-021.pdf (дата звернення: 09.07.2018).

5. Калюжний Р. А. Форми та методи адміністративно-правового забезпечення безпеки авіаційних перевезень. Наше право. 2012. № 1; ч. І. С. 36-42.

6. Михалюк С. Правотворчість як складова державного управління. Вісник Національної академії державного управління. 2009. Вип. 1. С. 191-197 URL: http://visnyk.academy.gov.ua/wp-content/uploads/2013/11/2009-1-26.pdf (дата звернення: 26.09.2018).

7. Скакун О. Ф. Теорія держави і права : підручник. Харків : Консум, 2001. 656 с.

8. Про мобілізаційну підготовку і мобілізацію : Закон України від 21.10.1993 № 3543-XII. Відомості Верховної Ради України. 1993. № 44. Ст. 416.

9. Кукурудз Т. Ю. Адміністративний договір: крок назад або вимога сьогодення // rusnauka: сайт URL: http://www.rusnauka.com/9._EISN_2007/Pravo/21413.doc.htm (дата звернення: 26.09.2018).

10. Адміністративне право України : підручник / Ю. П. Битяк, В. М. Гаращук, О. В. Дьяченко та ін. ; за ред. Ю. П. Битяка. Київ : Юрінком Інтер, 2007. 544 с.

11. Бояринцева М. А. Адміністративний договір: дискусійні питання правової природи та правосуб’єктності сторін. Вісник Вищої ради юстиції. 2011. № 2 (6). С. 79-94.

12. Адміністративна юрисдикція України: проблеми теорії і практики. Настільна книга судді / за заг. ред. О. М. Пасенюка. Київ : Істина, 2007. 607 с.

13. Сдинак Т. С., Павлишен О. В. Контроль як функція державного управління: сутність та класифікація. Вісник Академії митної служби України. Серія: Державне управління. 2011. № 1. С. 12-18.

14. Адміністративне право України : підручник / за заг. ред. Т. О. Коломієць. Вид. 2, змін. $\mathrm{i}$ доп. Київ : Істина, 2012. 528 с.

15. Нашинець-Наумова А. Ю. Методи адміністративно-правового регулювання діяльності корпорацій в Україні. Юридичний вісник. 2012. Вип. 2 (23). С. 56-59.

16. Кузніченко С. О. Становлення та розвиток інституту надзвичайних адміністративно-правових режимів в Україні : дис. ... д-ра юрид. наук : 12.00.07. Сімферополь, 2010. 463 с.

17. Адміністративне право України: підручник / Ю. П. Битяк (кер. авт. кол.), В. М. Гаращук, В. В. Богуцький та ін. ; за заг. ред. Ю. П. Битяка, В. М. Гаращука, В. В. Зуй. Харків : Право, 2012. 656 с.

18. Крушельницький М. А. Військове виховання в Україні: історичний досвід і проблеми сучасності // Lviv Polytechnic National University Institutional Repository. C. 145-153. URL: http://ena.lp.edu.ua/bitstream/ntb/8540/1/22.pdf (дата звернення: 26.09.2018).

19. Військово-патріотичне виховання у Збройних Силах України // Міністерство оборони України : офіц. веб-сайт. URL: http://www.mil.gov.ua/diyalnist/vijskovo-patriotichnarobota/vijskovo-patriotichne-vihovannya-u-zbrojnih-silah-ukraini.html (дата звернення: 26.09.2018).

20. Гірше, ніж у 90-х: воєнком розповів про осінній призов, українців виловлюють просто на вулиці // Znaj.ua : веб-сайт. URL: https://znaj.ua/society/185839-girshe-nizh-u-90-ihvoyenkom-rozpoviv-pro-osinniy-prizov-ukrajinciv-vilovlyuyut-prosto-na-vulici (дата звернення: 26.09.2018).

21. Комзюк А. Т. Заходи адміністративного примусу в правоохоронній діяльності міліції: поняття, види та організаційно-правові питання реалізації : монографія / за заг. ред. О. М. Бандурки. Харків : Нац. ун-т внутр. справ, 2002. 336 с.

22. Лазаренко В. А. Адміністративно-правове регулювання екологічної безпеки в Україні : дис. ... канд. юрид. наук : 12.00.07. Київ, 2010. 210 с. 
23. Ткаля О. В. Адміністративно-правовий вплив на неправомірну поведінку: теоретичний аспект. Правовий вплив на неправомірну поведінку: актуальні грані : монографія / за ред. О. В. Козаченка, Є. Л. Стрельцова. Миколаїв : Іліон, 2016. С. 425-450.

24. Бурбика М. М., Солонар А. В., Янішевська К. Д. Адміністративне право України : навч. посіб. Суми : Мрія, 2015. 358 с.

25. Конституція України : Закон України від 28.06.1996 № 254к/96-ВР. Відомості Верховної Ради України.1996. № 30. Ст. 141.

26. Державне управління : підручник : у 2 т. / ред. кол.: Ю. В. Ковбасюк, К. О. Ващенко, Ю. П. Сурмін та ін. Київ : Нац. акад. держ. упр. при Президентові України ; Дніпропетровськ : НАДУ, 2012. Т. 1.564 с.

27. Державне управління : навч. посіб. / А. Ф. Мельник, О. Ю. Оболенський, А. Ю. Васіна, Л. Ю. Гордієнко ; за ред. А. Ф. Мельник. Київ : Знання-Прес, 2003. 343 с.

28. Стеценко С. Г. Адміністративне право України : навч. посіб.. Київ : Атіка, 2007. 624 с. URL: http://radnuk.info/pidrychnuku/493-stetsenko/9849-s-3---.html (дата звернення: 26.09.2018).

\section{References}

1. Bilko K. F. Formy i metody administratyvno-pravovogo regulyuvannya organizaciyi ta diyalnosti notariatu. Pravova derzhava. 2015. Vyp. 26. S. 542-549.

2. Filippov A. V. Administratyvno-pravove zabezpechennya bezpeky cyvilnoyi aviaciyi v Ukrayini : dys. ... kand. yuryd. nauk : 12.00.07. Kyyiv, 2010. 246 s.

3. Administratyvne pravo Ukrayiny. Akademichnyj kurs : pidruch. : u 2 t. : T. 1. Zagalna chastyna / red. kolegiya: V. B. Averyanov (golova). Kyyiv : Yurydychna dumka, 2004. 584 s.

4. Blikhar M. M. Metody administratyvno-pravovogo regulyuvannya investycijnoyi diyalnosti $\mathrm{v}$ Ukrayini // Lviv Polytechnic National University Institutional Repository. S. 16-21. URL: http:// http://ena.lp.edu.ua/bitstream/ntb/26599/1/004-016-021.pdf (data zvernennya: 09.07.2018).

5. Kalyuzhnyj R. A. Formy ta metody administratyvno-pravovogo zabezpechennya bezpeky aviacijnyx perevezen. Nashe pravo. 2012. \# 1; ch. I. S. 36-42.

6. Mykhalyuk S. Pravotvorchist yak skladova derzhavnogo upravlinnya. Visnyk Nacionalnoyi akademiyi derzhavnogo upravlinnya. 2009. Vyp. 1. S. 191-197 URL: http://visnyk.academy.gov.ua/wp-content/uploads/2013/11/2009-1-26.pdf (data zvernennya: 26.09.2018).

7. Skakun O. F. Teoriya derzhavy i prava : pidruchnyk. Xarkiv : Konsum, 2001. 656 s.

8. Pro mobilizacijnu pidgotovku i mobilizaciyu : Zakon Ukrayiny vid 21.10.1993 \# 3543-XII. Vidomosti Verkhovnoyi Rady Ukrayiny. 1993. \# 44. St. 416.

9. Kukurudz T. Yu. Administratyvnyj dogovir: krok nazad abo vymoga sogodennya // rusnauka: sajt URL: http://www.rusnauka.com/9._EISN_2007/Pravo/21413.doc.htm (data zvernennya: 26.09.2018).

10. Administratyvne pravo Ukrayiny : pidruchnyk / Yu. P. Bytyak, V. M. Garashhuk, O. V. Dyachenko ta in. ; za red. Yu. P. Bytyaka. Kyyiv : Yurinkom Inter, 2007. 544 s.

11. Boyarynceva M. A. Administratyvnyj dogovir: dyskusijni pytannya pravovoyi pryrody ta pravosubyektnosti storin. Visnyk Vyshhoyi rady yustyciyi. 2011. \# 2 (6). S. 79-94.

12. Administratyvna yurysdykciya Ukrayiny: problemy teoriyi i praktyky. Nastilna knyga suddi / za zag. red. O. M. Pasenyuka. Kyyiv : Istyna, 2007. 607 s.

13. Yedynak T. S., Pavlyshen O. V. Kontrol yak funkciya derzhavnogo upravlinnya: sutnist ta klasyfikaciya. Visnyk Akademiyi mytnoyi sluzhby Ukrayiny. Seriya: Derzhavne upravlinnya. 2011. \# 1. S. 12-18.

14. Administratyvne pravo Ukrayiny: pidruchnyk / za zag. red. T. O. Kolomiyecz. Vyd. 2, zmin. i dop. Kyyiv : Istyna, 2012. $528 \mathrm{~s}$.

15. Nashynecz-Naumova A. Yu. Metody administratyvno-pravovogo regulyuvannya diyalnosti korporacij v Ukrayini. Yurydychnyj visnyk. 2012. Vyp. 2 (23). S. 56-59. 
16. Kuznichenko S. O. Stanovlennya ta rozvytok instytutu nadzvychajnykh administratyvnopravovykh rezhymiv v Ukrayini : dys. ... d-ra yuryd. nauk : 12.00.07. Simferopol, 2010. $463 \mathrm{~s}$.

17. Administratyvne pravo Ukrayiny: pidruchnyk / Yu. P. Bytyak (ker. avt. kol.), V. M. Garashhuk, V. V. Boguczkyj ta in. ; za zag. red. Yu. P. Bytyaka, V.M. Garashhuka, V. V. Zuj. Kharkiv : Pravo, 2012. $656 \mathrm{~s}$.

18. Krushelnyczkyj M. A. Vijskove vykhovannya v Ukrayini: istorychnyj dosvid i problemy suchasnosti // Lviv Polytechnic National University Institutional Repository. S. 145-153. URL: http://ena.lp.edu.ua/bitstream/ntb/8540/1/22.pdf (data zvernennya: 26.09.2018).

19. Vijskovo-patriotychne vykhovannya u Zbrojnykh Sylakh Ukrayiny // Ministerstvo oborony Ukrayiny : oficz. veb-sajt. URL: http://www.mil.gov.ua/diyalnist/vijskovo-patriotichnarobota/vijskovo-patriotichne-vihovannya-u-zbrojnih-silah-ukraini.html (data zvernennya: 26.09.2018).

20. Girshe, nizh u 90-x: voyenkom rozpoviv pro osinnij pryzov, ukrayinciv vylovlyuyut prosto na vulyci // Znaj.ua : veb-sajt. URL: https://znaj.ua/society/185839-girshe-nizh-u-90-ihvoyenkom-rozpoviv-pro-osinniy-prizov-ukrajinciv-vilovlyuyut-prosto-na-vulici (data zvernennya: 26.09.2018).

21. Komzyuk A. T. Zaxody administratyvnogo prymusu v pravookhoronnij diyalnosti miliciyi: ponyattya, vydy ta organizacijno-pravovi pytannya realizaciyi : monografiya / za zag. red. O. M. Bandurky`. Xarkiv : Nacz. un-t vnutr. sprav, 2002. 336 s.

22. Lazarenko V. A. Administraty`vno-pravove regulyuvannya ekologichnoyi bezpeky v Ukrayini : dys. ... kand. yuryd. nauk : 12.00.07. Kyyiv, 2010. $210 \mathrm{~s}$.

23. Tkalya O. V. Administratyvno-pravovyj vplyv na nepravomirnu povedinku: teoretychnyj aspekt. Pravovyj vplyv na nepravomirnu povedinku: aktualni grani : monografiya / za red. O. V. Kozachenka, Ye. L. Strelczova. Mykolayiv : Ilion, 2016. S. 425-450.

24. Burbyka M. M., Solonar A. V., Yanishevska K. D. Administratyvne pravo Ukrayiny : navch. posib. Sumy : Mriya, 2015. 358 s.

25. Konstytuciya Ukrayiny : Zakon Ukrayiny vid 28.06.1996 \# 254k/96-VR. Vidomosti Verkhovnoyi Rady Ukrayiny.1996. \# 30. St. 141.

26. Derzhavne upravlinnya : pidruchnyk : u 2 t. / red. kol.: Yu. V. Kovbasyuk, K. O. Vashhenko, Yu. P. Surmin ta in. Kyyiv : Nacz. akad. derzh. upr. pry Prezydentovi Ukrayiny ; Dnipropetrovsk : NADU, 2012. T. $1.564 \mathrm{~s}$.

27. Derzhavne upravlinnya : navch. posib. / A. F. Melnyk, O. Yu. Obolenskyj, A. Yu. Vasina, L. Yu. Gordiyenko ; za red. A. F. Melnyk. Kyyiv : Znannya-Pres, 2003. 343 s.

28. Stecenko S. G. Administratyvne pravo Ukrayiny : navch. posib.. Kyyiv : Atika, 2007. 624 s. URL: http://radnuk.info/pidrychnuku/493-stetsenko/9849-s-3---.html (data zvernennya: 26.09.2018).

(C) 2019 by the authors; Social development \& Security, Ukrainian. This is an open access article distributed under the terms and conditions of the Creative Commons Attribution (CCBY) license (http://creativecommons.org/licenses/by/4.0/). 